\title{
Anna Król
}

Uniwersytet Ekonomiczny we Wrocławiu

\section{AN ANALYSIS OF THE DYNAMICS \\ OF HIGHER EDUCATION'S INFLUENCE ON THE LEVEL OF WAGES ${ }^{1}$}

\begin{abstract}
Summary: The paper focuses on an assessment of the changes over time in tertiary education's influence on the level of wages with the application of the Mincerian earnings function method. The conducted empirical research allowed for the identification of growth patterns in the so called pseudo rate of return to higher education in Poland and Germany in the last decade (using data from the Polish Social Diagnosis and German Socio-Economic Panel Study (SOEP)). In addition, an analysis of dynamics of influence of auxiliary factors on earnings (such as gender, geographical location, character of work etc.) is given. Since 1998, when the Sorbonne Declaration was signed, the development and modernization of higher education have been the priorities of the European Union policies. A significant part of the postulated reforms require changes in the area of funding of universities, in particular encouraging a shift from centralized input oriented funding mechanisms towards decentralized outcome oriented financing. In that context one of the key problems is the measurement of the efficiency and effectiveness of various aspects of higher universities activities, including the education area.
\end{abstract}

Keywords: Mincer model, pseudo rate of return to tertiary education, dynamic analysis DOI: $10.15611 /$ ekt.2014.1.05

\section{Introduction}

Since 1998, when the Sorbonne Declaration was signed and the European Higher Education Area was established, the development and modernization of higher education have been the priorities of the European Union's policies. The following EU declarations and initiatives were aimed at the harmonization and unification of European higher education in order to encourage the mobility of both students and teachers (the Bologna Declaration), gaining economic competitive dominance by

${ }^{1}$ The study was conducted in the framework of the research project entitled Rate of Return Measurement Methods in Higher Education (Metody pomiaru stopy zwrotu z inwestycji na edukacje w szkotach wyższych). The project has been financed by the National Science Centre on the basis of decision no DEC-2011/01/B/HS4/02328. 
means of investments in innovative research and development (the Lisbon Strategy), increasing the number of students and preventing qualifications deficiency by supporting higher education, research and economic development, as well as employment (the Higher Education Modernisation Agenda and Europe 2020 growth strategy).

The contemporary research and education market, with its increasing number of students, globalization, rapid technological development, growing research costs, emergence of specialized university-independent B $+\mathrm{R}$ centres, and the increasing significance of commercialization and entrepreneurship, poses many challenges for traditional universities and enforces their transformation (cf. [Wissema 2009, pp. 24-44;). In order to ensure the better quality, effectiveness and accessibility of higher education among all EU countries the shift from the traditional Humboldtian university type towards the modern entrepreneurial university type, in which conventional functioning areas - education and research - are supplemented by other fields such as research commercialization, application for external grants and projects as well as co-operation with industry ${ }^{2}$.

A significant part of the postulated reforms in the functioning of universities require changes in the area of funding, in particular encouraging a shift from a centralized input oriented funding mechanisms towards a decentralized outcome oriented financing. In that context, one of the key problems is the measurement of the efficiency and effectiveness of various aspects of higher universities' activities, including the education area, in order to create an adequate system of fund allocation (cf. [Dziechciarz 2011]).

The aim of this paper is to assess the changes over time in tertiary education's influence on the level of wages with the application of the Mincerian earnings function method and to identify growth patterns in the so called pseudo rate of return to higher education in Poland and Germany in the last decade. The obtained results provide the basis for the evaluation of the effectiveness of private investment in education and its evolution.

\section{Research methodology}

Measuring the effectiveness and quality of education is a complex and multi-dimensional task for which numerous methods and techniques may be applied ${ }^{3}$. The benefits derived from education as well as expenditures on education might be measured from the point of view of various entities (e.g. students, teachers, university,

${ }^{2}$ For a detailed comparison of second and third generation university characteristics see e.g. [Dziechciarz-Duda, Król 2012].

${ }^{3}$ An extensive overview of quality measures in education may be found for example in [Targaszewska 2011]. 
society) and in many aspects (e.g. monetary vs. nonmonetary approach ${ }^{4}$ ). As a result to capture the numerous aspects of the effectiveness of investment in education a set of indicators must be used, each of them adequately describing some part of the analysed problem.

A commonly used method of measuring the monetary effectiveness of investment in education ${ }^{5}$ (including higher education) from the point of view of a student is the private rate of return to education, which may be calculated using the following general formula:

$$
r=\frac{C I F-C O F}{C O F} \cdot 100 \%,
$$

where $C I F$ - present value of future cash inflows resulting from the fact of obtaining higher education (also called premium for higher education), COF - present value of all cash outflows spent on the investment in higher education (including the costs of lost opportunities). Since $C O F \mathrm{~s}$ are especially difficult to estimate (due to their individual character and lack of adequate datasets), often only CIFs are evaluated in the form of the earnings premium obtained by people with higher education in comparison to the earnings of people without it. This increase in earnings resulting from investment in higher education is referred to as the pseudo rate of return to education.

To analyse the dynamics of influence of education level on wages, the commonly applied ${ }^{6}$ Mincerian earnings function [Mincer 1958; 1974] was used:

$$
\ln W_{i}=\mathbf{X}_{i}^{T} \boldsymbol{\beta}+\varepsilon_{i},
$$

where $W$-wages, $\mathbf{X}$ - vector of variables influencing wages, $\boldsymbol{\beta}$ - vector of unknown parameters, $\boldsymbol{\varepsilon}$-error term. The elements of $\mathbf{X}$ usually describe education (represented by the number of years of education or dummies for level of education, the latter providing the estimation of the pseudo rate of return to education) and professional experience, as well as auxiliary characteristics such as gender, region, place of work, position etc.

Even though the assumptions of the Mincer model justify the log-linear functional form expressed in formula (2) (cf. [Heckman et al. 2003]), in addition the Box-Cox transformation was used [Box, Cox 1964]:

$$
B\left(W_{i}, \alpha\right)=\left\{\begin{array}{ll}
\frac{W_{i}^{\alpha}-1}{\alpha} & \text { dla } \alpha \neq 0 \\
\ln \left(W_{i}\right) & \text { dla } \alpha=0
\end{array},\right.
$$

\footnotetext{
${ }^{4}$ For a discussion on the non-monetary aspects of effectiveness of education see e.g. [Dziechciarz-Duda, Król 2013].

${ }^{5}$ For a summary of the different approaches to measuring the effectiveness of education see e.g. [Dziechciarz 2011; Dziechciarz, Król, Targaszewska 2014].

${ }^{6}$ [Psacharopoulos 2009] provides a review of numerous empirical papers using this approach.
} 
to choose between linear $(\alpha=1)$ and $\log$-linear $(\alpha=0)$ specification. The choice of the independent variables in vector $\mathbf{X}$, crucial for the correctness of the model (2), was in the first placed dictated by the theoretical basis of the earnings function, and later verified by the availability and quality of the data. The final specifications were derived using data-driven methods (i.e. AIC, SC). Since heteroskedasticity of error term was detected in the large majority of cases (using the White test), for model estimation either the ordinary least squares method with heteroskedasticity corrected standard errors was used (cf. [White 1980]) or the weighted least squares method (White's approach) was applied.

\section{Datasets description and preparation}

The empirical research was based on two datasets: the German Socio-Economic Panel Study (SOEP) [Wagner et al. 2007] and the Polish Social Diagnosis [Rada Monitoringu Społecznego 2003-2011].

The German Socio-Economic Panel Study (SOEP) is an annual wide-ranging representative longitudinal study of private households which started in 1984. The data provide information on households and its members and some of its many topics include household composition, occupational biographies, employment, earnings, health and satisfaction indicators.

The Social Diagnosis is a panel study investigating households and their occupants aged 16 and above. The project takes into account all the significant aspects of life, both economic (i.e. income, material wealth, savings and financing), and the not strictly economic (i.e. education, medical care, problem-solving, stress, psychological well-being, lifestyle, pathologies, engagement in the arts and cultural events). The first sample was taken in 2000. The following took place three years later, and has since been repeated every two years.

Table 1 provides a comparison of the two databases and variables which were selected and used in the research.

Table 1. Comparison of datasets used in research

\begin{tabular}{|l|l|l|}
\hline & Socio-Economic Panel Study (SOEP) & \multicolumn{1}{|c|}{ Social Diagnosis } \\
\hline \multicolumn{1}{|c|}{2} & \multicolumn{1}{|c|}{2} & \multicolumn{1}{c|}{3} \\
\hline Country & Germany & Poland \\
\hline Panel website & http://panel.gsoep.de/ & http://www.diagnoza.com/ \\
\hline Panel waves & Annual in the period 1984-2011 & $\begin{array}{l}\text { Biennial in the period 2003-2011 } \\
\text { and initial wave in the year 2000 }\end{array}$ \\
\hline $\begin{array}{l}\text { Years analysed } \\
\text { in the research }\end{array}$ & $1995,2000,2005,2010$ & 2003, 2005, 2007, 2009, 2011 \\
\hline Dependent variable & $\begin{array}{l}\text { Logarithm of hourly gross earnings } \\
(\ln (H G E A R))\end{array}$ & $\begin{array}{l}\text { Logarithm of monthly net earnings } \\
(\ln (M N E A R))\end{array}$ \\
\hline
\end{tabular}


Table 1, cont.

\begin{tabular}{|l|l|l|}
\hline \multicolumn{1}{|c|}{1} & \multicolumn{1}{|c|}{2} & \multicolumn{1}{|c|}{3} \\
\hline $\begin{array}{l}\text { Independent } \\
\text { variables describing } \\
\text { education level }\end{array}$ & $\begin{array}{l}\text { Dummy for higher education } \\
(H E D U)\end{array}$ & $\begin{array}{l}\text { Dummy for higher and middle } \\
\text { education }(H E, M E)\end{array}$ \\
\hline $\begin{array}{l}\text { Independent } \\
\text { variables describing } \\
\text { professional } \\
\text { experience }\end{array}$ & $\begin{array}{l}\text { Potential work experience }(P W E) \text { and } \\
\text { seniority in the current workplace } \\
(S E N), \text { and their squares }\end{array}$ & $\begin{array}{l}\text { Work experience }(E X P) \text { and age } \\
(A G E), \text { and their squares }\end{array}$ \\
\hline $\begin{array}{l}\text { Independent } \\
\text { variables describing } \\
\text { work character }\end{array}$ & $\begin{array}{l}\text { Dummies for work types: apprentice } \\
(A P P), \text { specialist }(S P E C), \text { freelance } \\
(P R O F), \text { manager }(M A N), \text { others } \\
(O T H E R)\end{array}$ & $\begin{array}{l}\text { Dummies for work sectors: public } \\
(P U B), \text { private }(P R I V), \text { own business } \\
(E N T), \text { other }(O T H)\end{array}$ \\
\hline $\begin{array}{l}\text { Independent } \\
\text { variables describing } \\
\text { the place of work }\end{array}$ & $\begin{array}{l}\text { Dummies for the size of the } \\
\text { company: less than employees } \\
(S M A L L), \text { between 20 and 2 000 } \\
\text { employees }(M E D I U M), \text { more than } \\
2 \text { O00 employees }(L A R G E)\end{array}$ & $\begin{array}{l}\text { Dummies for the type of residence: } \\
\text { big cities with more than 100 thousand } \\
\text { occupants }(B C I T Y), \text { small and medium } \\
\text { cities with less than 100 thousand } \\
\text { occupants }(M C I T Y), \text { villages }(V I L)\end{array}$ \\
\hline $\begin{array}{l}\text { Other independent } \\
\text { variables }\end{array}$ & $\begin{array}{l}\text { Dummy for gender }(F E M) \\
\text { Dummies for gender }(F) \text { and } \\
\text { geographical localisation: eastern } \\
\text { Poland }(E A S T), \text { western Poland } \\
(W E S T)\end{array}$ \\
\hline
\end{tabular}

Source: own elaboration.

For the sake of conciseness, the list of variables and summary statistics for the Social Diagnosis dataset only for the year 2009 are presented in Table 2 and just for demonstrative purposes - information for the other analysed years will be omitted. Similarly, the description and basic summary statistics for the SOEP dataset in the year 2010 may be found in [Dziechciarz-Duda, Król 2012] and will not be additionally discussed here.

Table 2. Description of variables and summary statistics in 2009

\begin{tabular}{|l|l|l|c|c|c|}
\hline $\begin{array}{c}\text { Variable } \\
\text { name }\end{array}$ & \multicolumn{1}{|c|}{ Description } & Scale type & Mean & $\begin{array}{c}\text { Standard } \\
\text { deviation }\end{array}$ & $\begin{array}{c}\text { Dataset } \\
\text { structure } \\
\text { in \%* }\end{array}$ \\
\hline 1 & \multicolumn{1}{|c|}{2} & \multicolumn{1}{c|}{3} & 4 & 5 & 6 \\
\hline MNEAR & Monthly net earnings & ratio & 1350.00 & 707.72 & \\
\hline$H E$ & $\begin{array}{l}\text { Higher education (1 for tertiary or } \\
\text { higher level education, 0 otherwise) }\end{array}$ & $\begin{array}{l}\text { nominal } \\
\text { (dichotomic) }\end{array}$ & & & 10.83 \\
\hline$M E$ & $\begin{array}{l}\text { Medium education (1 for medium } \\
\text { level education, 0 otherwise) }\end{array}$ & $\begin{array}{l}\text { nominal } \\
\text { (dichotomic) }\end{array}$ & & & 36.17 \\
\hline$Y O E$ & Years of education & ratio & 11.54 & 3.31 & 63.37 \\
\hline
\end{tabular}




\begin{tabular}{|c|c|c|c|c|c|}
\hline 1 & 2 & 3 & 4 & 5 & 6 \\
\hline$A G E$ & Age & ratio & 48.77 & 18.01 & \\
\hline EXP & Professional experience years & ratio & 22.36 & 13.91 & \\
\hline WSEC & $\begin{array}{l}\text { Work sector (public }(P U B), \text { private } \\
(P R I V) \text {, own business }(E N T) \text {, other } \\
(O T H))\end{array}$ & $\begin{array}{l}\text { nominal } \\
\text { (categorical) }\end{array}$ & & & $\begin{array}{r}14.21 \\
24.08 \\
3.20 \\
58.51\end{array}$ \\
\hline CTYPE & $\begin{array}{l}\text { The type of residence: big cities with } \\
\text { more than } 100 \text { thousand occupants } \\
(B C I T Y) \text {, small and medium } \\
\text { cities with less than } 100 \text { thousand } \\
\text { occupants }(M C I T Y) \text {, villages }(V I L)\end{array}$ & ordinal & & & $\begin{array}{l}23.92 \\
32.90 \\
43.18\end{array}$ \\
\hline$F$ & Gender ( 1 if female, 0 otherwise) & $\begin{array}{l}\text { nominal } \\
\text { (dichotomic) }\end{array}$ & & & $\begin{array}{l}54.79 \\
45.21\end{array}$ \\
\hline EAST & $\begin{array}{l}\text { Geographical localisation** ( } 1 \text { if } \\
\text { eastern Poland, } 0 \text { otherwise) }\end{array}$ & $\begin{array}{l}\text { nominal } \\
\text { (dichotomic) }\end{array}$ & & & $\begin{array}{l}26.52 \\
73.48\end{array}$ \\
\hline
\end{tabular}

* For categorical and dichotomic variables the percentage for each category is reported.

** Eastern Poland includes the Lubelskie, Podkarpackie, Podlaskie, Świętokrzyskie and Warmińsko-Mazurskie regions in accordance with the division incorporated in the European Operational Programme Development of Eastern Poland. These voivodships are considered to have lower living standards, a lower dynamic of economic development, poorly developed and inadequate transport infrastructure and insufficient growth factors, which might be reflected in the earnings of their residents.

Source: own elaboration.

Although the quality of datasets used was quite high all the data were carefully analysed and inspected against missing data and possible outlying and extreme observations. As for missing data handling, the simplest approach was adapted - the observations with missing values were discarded and no imputation mechanism was applied. Similarly all the observations which were considered as extreme (i.e. the observations whose values exceeded 1.5 time interquartile range) were deleted.

\section{The changes in the influence of tertiary education on wages in Germany in 1995-2010}

The starting point of the research was the initial results of the Mincer model estimation in 2010 described in [Dziechciarz-Duda, Król 2012]. The conducted further analyses consisting principally in outlier elimination and heteroskedasticity correction, allowed for the following changes in research methodology: 1) the Heckman correction was omitted (due to the insignificant influence of the correction on the final results as well as severe problems with missing data leading to considerable decreases in the number of observations); 2) the variable $M E D U$ (dummy for secondary education level) was omitted (due to its insignificance and the fact that almost 
all respondents in the datasets were educated at least secondary level). The research was conducted for 1995, 2000, 2005 and 2010. Table 3 presents the number of observations and adjusted $R^{2}$ for each year for the best model chosen.

Table 3. Number of observations and adjusted $R^{2}$ for SOEP and Social Diagnosis models

\begin{tabular}{|l|c|c|}
\hline \multicolumn{3}{|c|}{ SOEP } \\
\hline \multicolumn{1}{|c|}{ Year } & $n$ & $R^{2}$ \\
\hline 1995 & 7018 & 0.3355 \\
\hline 2000 & 12423 & 0.3468 \\
\hline 2005 & 9697 & 0.4081 \\
\hline 2010 & 8787 & 0.4153 \\
\hline & & \\
\hline
\end{tabular}

\begin{tabular}{|l|c|c|}
\hline \multicolumn{3}{|c|}{ Social Diagnosis } \\
\hline \multicolumn{1}{|c|}{ Year } & $n$ & $R^{2}$ \\
\hline 2003 & 6707 & 0.3486 \\
\hline 2005 & 5802 & 0.3015 \\
\hline 2007 & 9205 & 0.3072 \\
\hline 2009 & 18370 & 0.3660 \\
\hline 2011 & 18661 & 0.3541 \\
\hline
\end{tabular}

Source: own elaboration.

Figure 1 presents the dynamics of the influence of selected factors on earnings, with the premium for higher education on the plot (a). The results show that in the last 15 years in Germany the influence of tertiary education on the level of wages has increased steadily and approximately linearly by about $5 \%$ every 5 years. In 2010, Germans with higher education could earn about $25 \%$ more in comparison to similar (in terms of gender, work experience, work type, size of the company etc.) persons. In the same period few factors seemed to have exhibited no significant changes. An additional year of professional experience $(P W E)$ could bring about a $3 \%$ increase in the earnings, ceteris paribus. Similarly with each year of seniority in the last place of work $(S E N)$, wages on average increased by about $3 \%$. The influence of the size of the company on earnings was stable as well: the people who work in medium-size firms earned about $10 \%$ less, and small firms' employees earned about $25 \%$ less than people employed in big companies (see Figure 1, plot (d)). The factors whose influence changed the most are the ones connected with the type of work. The premium for managers $(M A N)$ increased from about $15 \%$ in 1995 to about $34 \%$ in 2010 (see Figure 1, plot (c)). Professionals and freelancers $(P R O F)$ in 2010 could earn about $31 \%$ more than regular employees, which is an increase of about $7 \%$ in comparison to 1995 . This result proves that labour market requirements extend beyond simply a higher education diploma, and that additional qualifications and skills are also important. Another interesting trend observed in the analysed period is the decrease of gender-related work discrimination (see Figure 1, plot (b)). Women in Germany earned in 2010 on average about $15 \%$ less than men in similar work positions and with similar professional experience (variable FEM). 
(a)

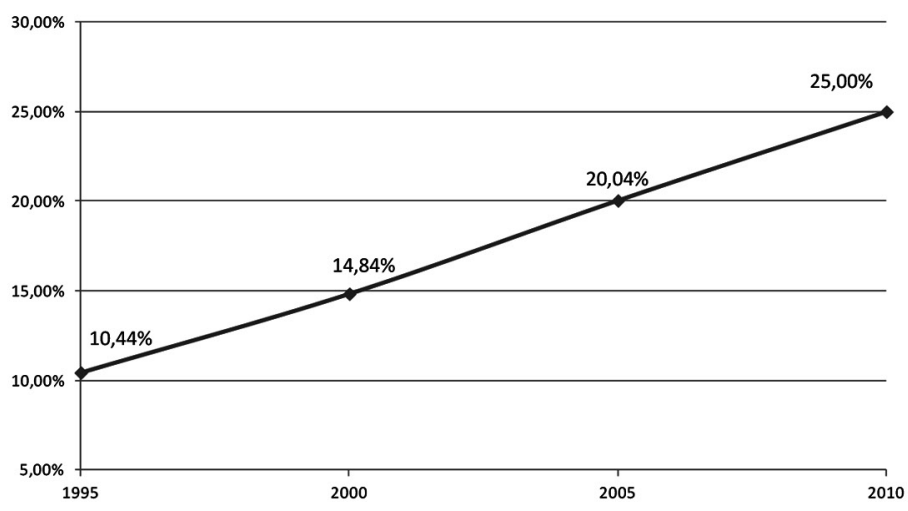

(c)

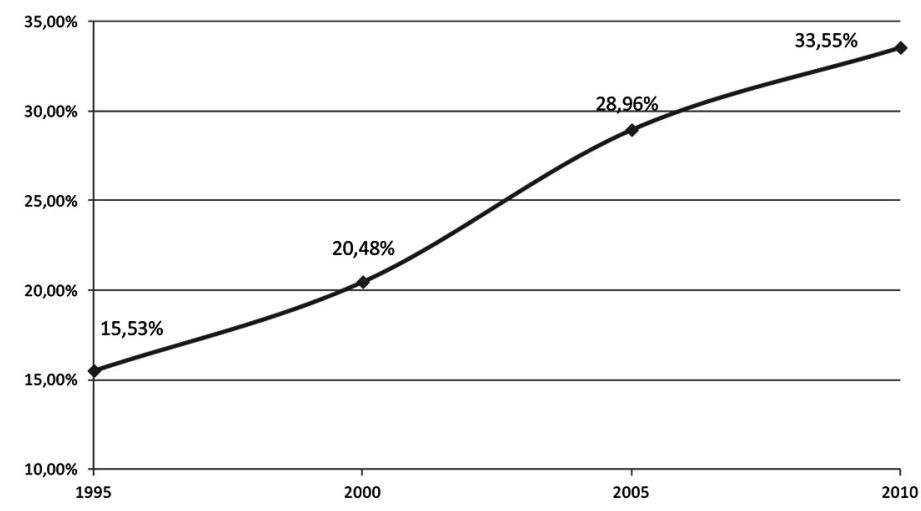

(b)

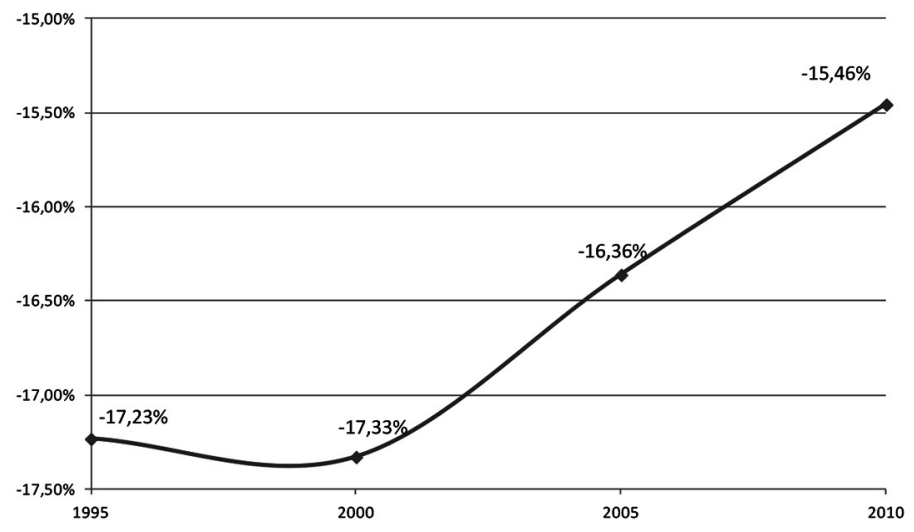

(d)

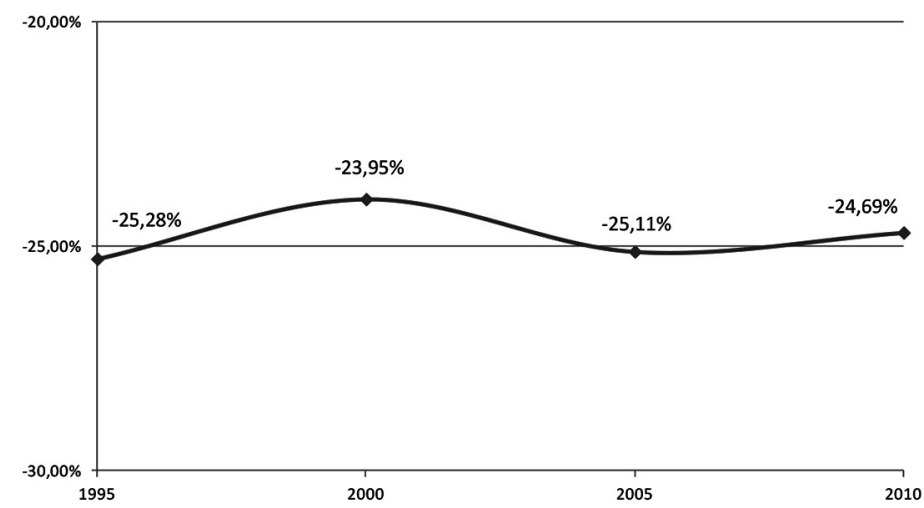

Fig. 1. The dynamics of influence on wages of: (a) tertiary education (HEDU), (b) gender (FEM), (c) work character (MAN), (d) size of the company (SMALL) in the years 1995-2010 based on the German SOEP dataset 


\section{Dynamics of higher education influence on the level of wages in Poland in 2003-2011}

The second part of the research was conducted using Polish Social Diagnosis datasets from the years 2003, 2005, 2007, 2009 and 2011. In each year, a few alternative specifications of vector $\mathbf{X}$ were estimated, starting with the simplest classic Mincer function which was afterwards extended by including dummies for secondary and tertiary education (variables $H E$ and $M E$ ) and a set of auxiliary gender-related, location-related and work type-related variables ${ }^{7}$. The results of estimation for 2009 are presented in Table 4.

Table 4. Estimation results of five different specifications of the Mincer model ( 2009) based on Social Diagnosis data

\begin{tabular}{|c|c|c|c|c|c|}
\hline $\begin{array}{l}\text { Dependent } \\
\text { variable } \\
\ln (M N E A R)\end{array}$ & $\begin{array}{l}\text { Model }^{\mathrm{a}} \\
\text { (1) }\end{array}$ & $\begin{array}{l}\text { Model } \\
\text { (2) }\end{array}$ & $\begin{array}{c}\text { Model } \\
\text { (3) }\end{array}$ & $\begin{array}{l}\text { Model } \\
\text { (4) }\end{array}$ & $\begin{array}{l}\text { Model } \\
\text { (5) }\end{array}$ \\
\hline constant & $0.6133^{* * *}$ & $6.8734 * * *$ & $6.7376^{* * *}$ & $6.9159 * * *$ & $6.7952 * * *$ \\
\hline YOET & $0.06484 * * *$ & & & & \\
\hline$E X P$ & $0.01195^{* * *}$ & $0.01404 * * *$ & $0.01354 * * *$ & $0.01105 * * *$ & $0.01288^{* * *}$ \\
\hline$E X P^{2}$ & $-0.00012 * * *$ & $-0.00025^{* * *}$ & $-0.00021^{* * *}$ & $-0.00008^{* * *}$ & $-0.00011^{* * *}$ \\
\hline$H E$ & & $0.4807 * * *$ & $0.6024 * * *$ & $0.3470 * * *$ & $0.4699 * * *$ \\
\hline$M E$ & & & $0.2887 * * *$ & & $0.2116 * * *$ \\
\hline MCITY & & & & $-0.0849 * * *$ & $-0.0658 * * *$ \\
\hline$V I L$ & & & & $-0.2194 * * *$ & $-0.1636^{* * *}$ \\
\hline$P U B$ & & & & $0.3909 * * *$ & $0.3662 * * *$ \\
\hline PRIV & & & & $0.4295^{* * *}$ & $0.3852 * * *$ \\
\hline$E N T$ & & & & $0.5190 * * *$ & $0.4745 * * *$ \\
\hline$E A S T$ & & & & $-0.0847 * * *$ & $-0.0873 * * *$ \\
\hline$F$ & & & & $-0.1933 * * *$ & $-0.2138 * * *$ \\
\hline $\mathrm{n}$ & 18417 & 18426 & 18426 & 18370 & 18370 \\
\hline Adj. $R^{2}$ & 0.1903 & 0.1182 & 0.1642 & 0.3330 & 0.3660 \\
\hline
\end{tabular}

${ }^{\text {a }}$ Stars indicate significance level (‘***’ means significance on the level 0,01).

Source: own elaboration.

The relevance of the log-linear functional form of the models was tested using the Box-Cox transformation. In all the investigated cases the value of parameter $\alpha$

${ }^{7}$ The choice of those variables was preceded by analysis of the sources of variation in monthly net income of Poles (using ANOVA) described in [Targaszewska 2013]. 
did not exceed 0,3 indicating the superiority of the log-linear approach over the linear approach. Figure 2 presents the plots of log-likelihood function for various values of parameter $\alpha$ for specifications (2) and (5) using data from 2009.

(a)

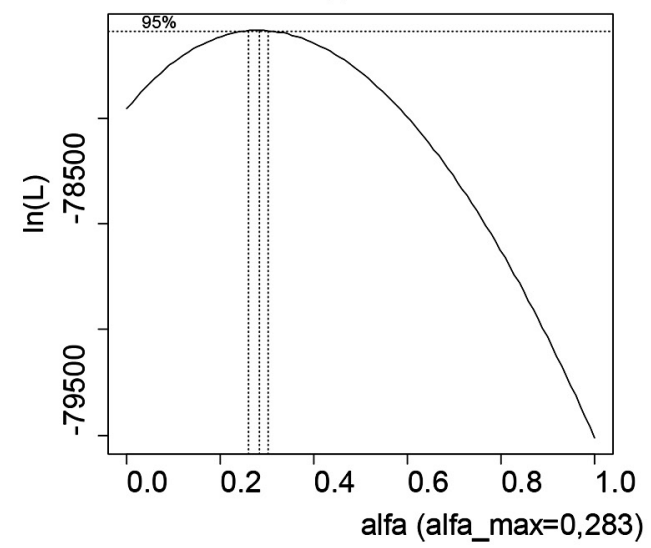

(b)

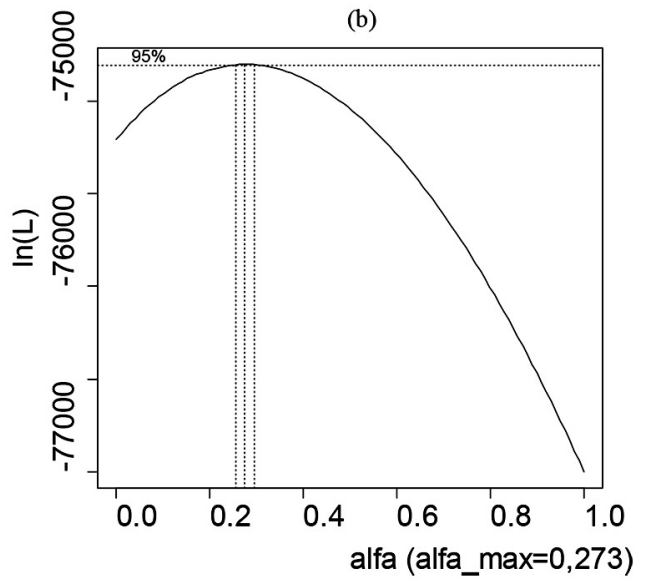

Fig. 2. The values of the log-likelihood function for various values of parameter a: (a) model (3), (b) model (5)

Source: own elaboration.

The obtained results provide evidence that higher education significantly influences the earnings of Poles. Depending on the specification, the premium for tertiary education diploma ${ }^{8}$ varies from $61.72 \%$ (model (1)) to $36.42 \%$ (model (5)). Similar$1 y$, all the other variables included in the widest specification are highly significant and the estimated parameters yield signs consistent with expectations. Moreover specification (5) provides the highest fit (about 36\%) and therefore it was chosen for the dynamic analysis of influence of the tertiary education on wages, presented in Figure 3.

The analysis of plot (a) in Figure 3 shows the stabilization of the premium for higher education in Poland in 2007-2011 on the level of about 36\%. The influence of secondary education on the level of earnings is likewise unvarying - Poles with secondary education earned on average about $25 \%$ more in comparison to people without it. The difference in wages between males and females in Poland is bigger than it was observed in Germany ${ }^{9}$. In the analysed period women earned on average about $20 \%$ less than men doing similar work in much the same work place (variable $F$ ).

\footnotetext{
${ }^{8}$ For the calculation of the influence of dummy variables the formula $(\exp (\hat{\beta})-1) \cdot 100 \%$ was used.

${ }^{9}$ Obviously due to differences in datasets from Germany and Poland, both in the analysed periods and the available variables, the obtained results cannot be compared without any stipulation. The article aims rather at juxtaposing the results than directly comparing them.
} 
(a)
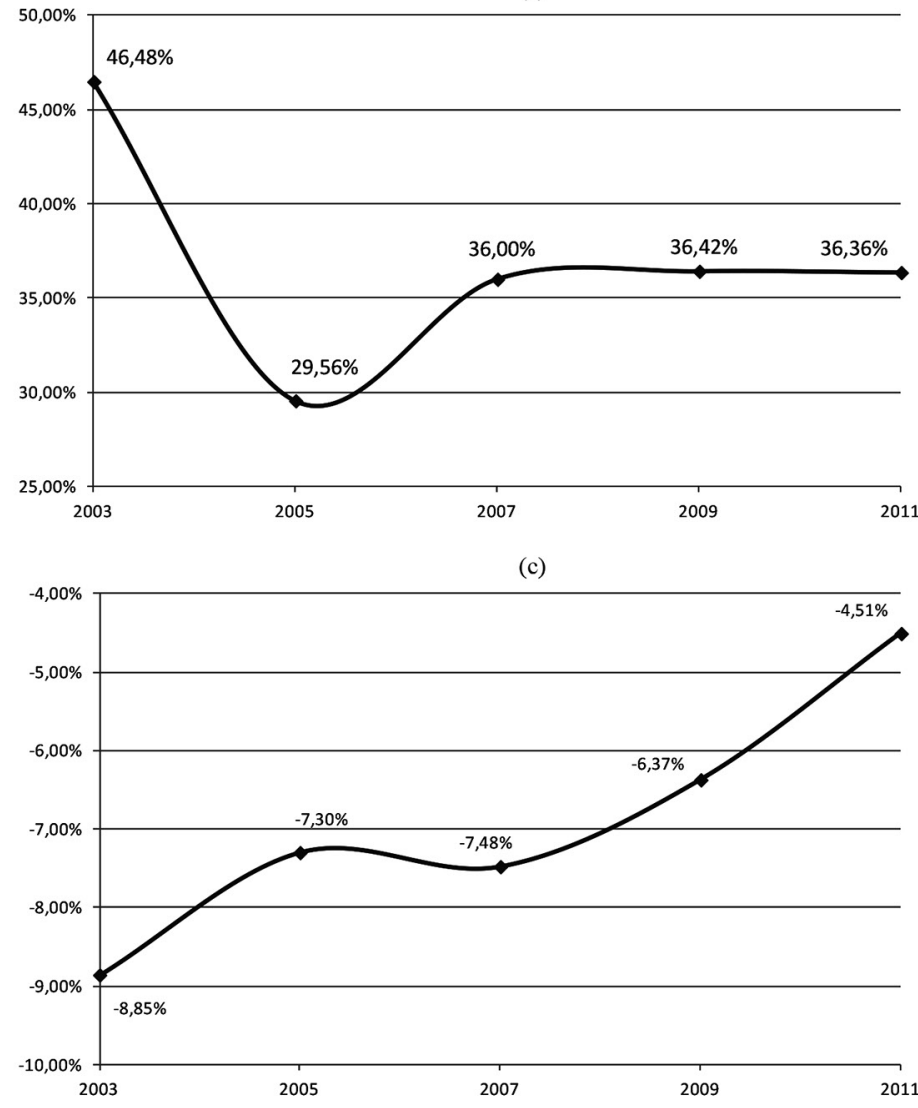

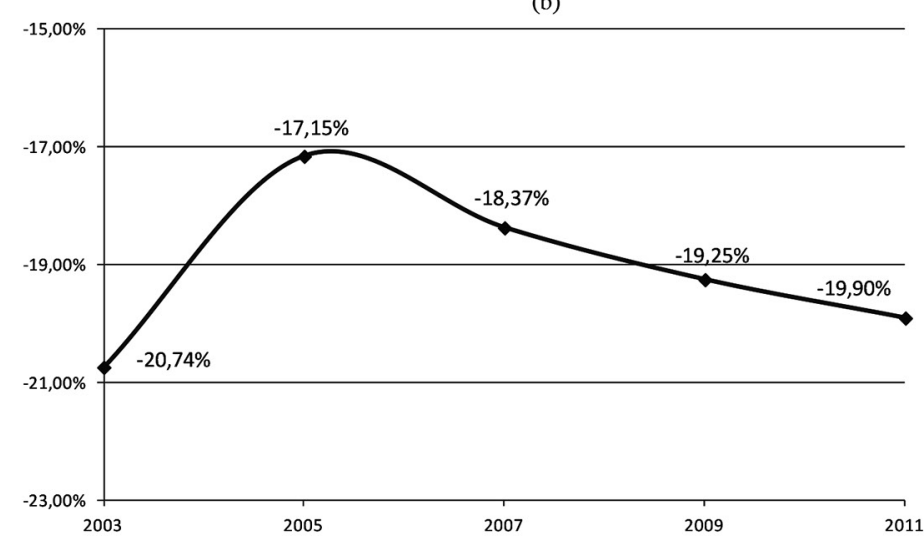

(d)

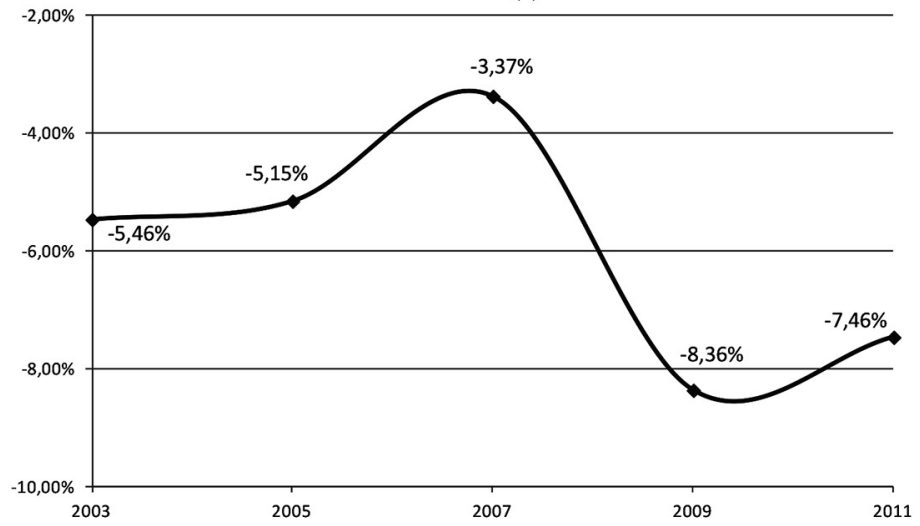

Fig. 3. The dynamics of influence on wages of: (a) tertiary education $(H E)$, (b) gender $(F)$, (c) type of residence $(M C I T Y)$, (d) geographical location (EAST) in 2003-2011 based on the Polish Social Diagnosis dataset

Source: own elaboration. 
The plots (c) and (d) show the influence of place of residence on the level of wages. Eastern Polish regions (EAST), which are considered to have lower living standards, a lower dynamic of economic development and insufficient growth factors prove to have significantly lower wages as well. In comparison to Central and West Poland, the people from eastern voivodships earned about $8 \%$ less, ceteris paribus. The residents of small and medium cities (MCITY) earned in 2011 about 5\% less than citizens of big cities, however their situation is gradually improving. In contrast, the situation of people living in villages $(V I L)$ is more constant over time. Their earnings in the period 2003-2009 have been on average about 15\% lower in comparison to the residents of large cities.

\section{Final remarks}

The aim of the conducted analyses was to assess the changes over time in tertiary education's influence on the level of wages with the application of the Mincerian earnings function method, and to identify growth patterns in the so-called pseudo rate of return to higher education in Poland and Germany in the last decade. In addition, an analysis of the dynamics of the influence of auxiliary factors on earnings (such as gender, geographical location, character of work etc.) was undertaken.

The obtained results may be summarized in the following points:

- the influence of higher education on the level of wages increased in Germany in the last 15 years from a level of about $10 \%$ to about $25 \%$, and in Poland in the last nine years stabilized at about $36 \%$;

- gender-related discrimination at work is still a serious problem, with about a $15 \%$ difference in earnings in Germany and about a 20\% difference in Poland, however slight improvement in this area may be observed;

- highly specialized professionals and managers earn significantly more (even up to $30 \%$ ) than regular employees and this tendency is increasing (based on SOEP data);

- geographical location considerably influences earnings - residents of small and medium cities and villages earn about $5 \%$ and $12 \%$ less than citizens of big cities respectively, additionally people living in eastern regions of Poland earn significantly smaller wages (based on Social Diagnosis data).

The obtained results provide the basis for the evaluation of the effectiveness of private investment in education and its evolution. Obviously the quite high (and increasing) level of premium for higher education does not necessarily indicate the high effectiveness of the investment in higher education. In order to obtain such results, adequate methods of assessing private outflows spent on education (including the costs of lost opportunities) must be elaborated. An empirical analysis of applicability of discounting methods of investment evaluation (i.e. NPV, IRR) should follow, bringing the actual rate of return to education estimates. 


\section{Literature}

Box G.E.P., Cox D.R., An analysis of transformations, "Journal of the Royal Statistical Society. Series B (Methodological)" 1964, vol. 26, no. 2, pp. 211-252.

Dziechciarz J., On rate of return measurement in education, "Research Papers of Wrocław University of Economics. Econometrics" 2011, vol. 194, pp. 49-66.

Dziechciarz-Duda M., Król A., Próba zastosowania modelu Mincera do oceny wpływu wyższego wyksztatcenia na poziom wymagrodzeń, „Prace Naukowe Unwersytetu Ekonomicznego we Wrocławiu. Ekonometria” 2012, vol. 3(37), pp. 56-69.

Dziechciarz-Duda M., Król A., On Nonmonetary benefits of tertiary education, "Research Papers of Wrocław University of Economics. Econometrics" 2013, in press.

Dziechciarz J., Król A., Targaszewska M., Various Approaches to Measuring Effectiveness of Tertiary Education, [in:] A. Geyer-Schulz, J. Pociecha (eds.), Proceedings of the Third Bilateral German-Polish Symposium on Data Analysis and Its Applications, KIT Press 2014, Karlsruhe, Germany, in press.

Heckman J.J., Lochner L., Todd P.E., Fifty Years of Mincer Earnings Regressions, NBER Working Papers (9732), National Bureau of Economic Research 2003.

Jongbloed B., Funding Higher Education: a View across Europe, European Centre for Strategic Management of Universities (ESMU), Brussels 2010.

Mincer J., Investment in human capital and personal income distribution, "Journal of Political Economy" 1958, vol. 66, no. 4, pp. 281-302.

Mincer J., Schooling, Experience and Earnings, Columbia University Press, New York 1974.

Psacharopoulos G., Returns to Investment in Higher Education. A European Survey, Progress in Higher Education Reform Across Europe, Center for Higher Education Policy Studies, Enschede 2009.

Rada Monitoringu Społecznego, Diagnoza społeczna: zintegrowana baza danych [2003, 2005, 2007, 2009, 2011], www.diagnoza.com, dostęp: 17.09.2012.

Targaszewska M., Methods of measuring quality in higher education, "Research Papers of Wrocław University of Economics. Econometrics" 2011, vol. 194, pp. 67-75.

Targaszewska M., An attempt to identify the sources of variation in monthly net income among people with higher education, "Research Papers of Wrocław University of Economics. Econometrics" 2013, in press.

Wagner G.G., Frick J.R., Schupp J., The German Socio-Economic Panel Study (SOEP) - Scope, Evolution and Enhancements, "Schmollers Jahrbuch" 2007, vol. 127, no. 1, pp. 139-169.

White H., A heteroskedasticity-consistent covariance matrix estimator and a direct test for heteroskedasticity, "Econometrica" 1980, vol. 48, no. 4, pp. 817-838.

Wissema J.G., Towards the Third Generation University. Managing the University in Transition, EE Publishintg, Cheltenham 2009.

\section{BADANIE DYNAMIKI WPEYWU WYŻSZEGO WYKSZTALCENIA NA POZIOM WYNAGRODZEŃ}

Streszczenie: Niniejszy artykuł koncentruje się na badaniu dynamiki wpływu wyższego wykształcenia na poziom wynagrodzeń za pomocą modelu Mincera. Przeprowadzona analiza pozwoliła na wyznaczenie tendencji zmian w czasie tzw. pseudostopy zwrotu z inwestycji w edukację wyższą w Polsce i w Niemczech w ostatnim dziesięcioleciu (na podstawie danych pochodzących z polskiej Diagnozy Społecznej oraz niemieckiego badania panelowe- 
go SOEP). Ponadto uzyskane wyniki dostarczają wiedzy o dynamice wpływu różnorodnych czynników (takich jak: płeć, lokalizacja, rodzaj wykonywanej pracy) na wynagrodzenia. Rozwój i modernizacja edukacji na poziomie wyższym jest jednym z priorytetów polityki Unii Europejskiej od czasu podpisania Deklaracji Sorbońskiej w roku 1998. Znacząca część postulowanych reform wymaga wprowadzenia zmian w obszarze finansowania uczelni wyższych, a w szczególności odejścia od scentralizowanego finansowania zorientowanego na zasoby w kierunku zdecentralizowanego finansowania zorientowanego na wyniki. W tym kontekście kluczowym zagadnieniem staje się mierzenie efektywności i skuteczności szkolnictwa wyższego w różnych jego aspektach, w tym również w obszarze edukacji.

Słowa kluczowe: model Mincera, prywatna stopa zwrotu z inwestycji w edukację, ujęcie dynamiczne. 